\title{
Assessment of the Physico-Chemical Parameters and Soil Pollution in Some Landfills at Ouagadougou
}

\author{
Bambara Telado Luc ${ }^{1}$, Doumounia Ali ${ }^{1}$, Ouédraogo Soumaila ${ }^{1}$, Kohio Niessan ${ }^{1}$, \\ Francois Zougmoré ${ }^{2}$
}

${ }^{1}$ Physics and Chemical Department, Institute of Sciences, Ouagadougou, Burkina Faso

${ }^{2}$ Physics Department, University Joseph KI-ZERBO, Ouagadougou, Burkina Faso

Email address:

telado.luc.bambara@gmail.com(B. T. Luc)

\section{To cite this article:}

Bambara Telado Luc, Doumounia Ali, Ouedraogo Soumaila, Kohio Niessan, Francois Zougmoré. Assessment of the Physico-Chemical Parameters and Soil Pollution in Some Landfills at Ouagadougou. International Journal of Environmental Monitoring and Analysis.

Vol. 9, No. 2, 2021, pp. 54-59. doi: 10.11648/j.ijema.20210902.14

Received: April 5, 2021; Accepted: April 20, 2021; Published: April 29, 2021

\begin{abstract}
The study was conducted to evaluate the physic-chemical parameters and pollution aspect of landfill soils. The soils samples were collected in some selected landfill, at Ouagadougou. Determinations of heavy metal concentrations, physicchemical parameters, calculation of geo-accumulation index and statistical analysis were undertaken. The atomic absorption spectrophotometer was used to determine the concentrations of heavy metals $(\mathrm{Cr}, \mathrm{Mn}, \mathrm{Fe}, \mathrm{Ni}, \mathrm{Cu}, \mathrm{Zn}, \mathrm{As}, \mathrm{Cd}, \mathrm{Hg}$, and $\mathrm{Pb})$ in the soils samples. This study reveals that the studied landfill contribute to increase the concentration of heavy metals $(\mathrm{Cr}, \mathrm{Mn}$, $\mathrm{Fe}, \mathrm{Ni}, \mathrm{Cu}, \mathrm{Zn}, \mathrm{As}, \mathrm{Hg}$ and $\mathrm{Pb}$ ) in soils. The $\mathrm{pH} \mathrm{KCl}$ of the studied landfill soils were less than 7, which reflects the acidic nature of the landfill soils. The Landfills soils were classified between 'practically uncontaminated', 'Uncontaminated to Moderate' and 'Moderate'. The geoaccumulation of $\mathrm{Cr}, \mathrm{Mn}, \mathrm{Fe}, \mathrm{Ni}$, and As were less than one for the studied landfills. The classifications show that the landfill soil from KARPALA and DAGNOIN were the moderate polluted with $\mathrm{Cu}, \mathrm{Zn}$ and $\mathrm{Pb}$. The $\mathrm{Cu}, \mathrm{Zn}$ and $\mathrm{Pb}$ were metal that contribute more in the pollution in the landfill soil at Ouagadougou. Statistical study reveals that increasing total organic matter tends to decrease the concentrations of manganese, zinc, copper and lead.
\end{abstract}

Keywords: Soil, Heavy Metals, Solid Waste, Landfill Sites

\section{Introduction}

In Burkina Faso, the rapid demographic evolution of the agglomeration continues to exacerbate the problems of housing expansion in the capital. According to INSD, the population of Ouagadougou increased from 1,475,223 in 2006 to 2,684,052 inhabitants in 2020 [1]. The increase in household and industrial waste is in line with that of the population. Approximately 600,000 tons of waste are generated annually, municipal technical services evacuate just over $50 \%$.

The amount of household waste has increased in recent decades due to accelerated population growth. This phenomenon is more critical in developing countries which do not have the resources to properly manage waste.

Public landfills have been the source of many environmental problems in recent years [2]. Heavy metals are one of the dangerous pollutants found in the soils of these landfills. Also, heavy metal pollution of soils, leachate, plants and groundwater in the vicinity of landfills is shown in several scientific publications [3-9].

The objective of this study is to know the impact of urban landfills on the concentration of heavy metals in soils and to assess the risk of soil pollution in the city of Ouagadougou. The soil samples were analyzed by atomic absorption spectrophotometry and the analyzed heavy metals were cadmium, lead, arsenic, chromium, manganese, iron, nickel, copper, mercury and zinc.

\section{Materials and Methods}

\subsection{Study Area}

Burkina Faso is located in the West Africa. Its area is 274,000 square kilometers. It shares its borders with 6 
countries, namely Mali to the north and west, Niger to the north and east, Benin to the south-east, Ghana and Togo to the south, the Côte-d'Ivoire to the west and south.

The Ouagadougou is administrative capital of Burkina Faso $\left(1^{\circ} 28\right.$ to $1^{\circ} 36$ west longitude and $12^{\circ} 20$ to $12^{\circ} 26$ north latitude) and is situated in the center part of the country. The table 1 shows the geographical coordinates of landfill where the soils samples have been appropriated.

Table 1. Geographical coordinates of landfill.

\begin{tabular}{lll}
\hline \multirow{2}{*}{ Sampling site } & \multicolumn{2}{l}{ Geographical coordinates } \\
\cline { 2 - 3 } & latitude & Longitude \\
\hline IDS & 12.356333 & -1.481067 \\
DAGNOIN & 12.366800 & -1.486100 \\
SIAO & 12.352150 & -1.487850 \\
KARPALA & 12.335683 & -1.472683 \\
UO1 & 12.377720 & -1.500574 \\
TOUDOUWEOGO & 12.422533 & -1.505533 \\
\hline
\end{tabular}

\subsection{Soil Sample Treatment Protocol}

Mechanical preparation consisted of sieving the soil samples through a certified 200 mesh ( 75 micron) sieve.

The test portion used is one gram. The samples were weighed using a PA214C balance from OHAUS PIONEER, precision $10-4$ gram and capacity $200 \mathrm{~g}$.

The mineralization consisted in mineralizing the samples weighed by aqua regia $(2.5 \mathrm{~mL}$ of $\mathrm{HNO} 3+7.5 \mathrm{~mL}$ of $\mathrm{HCl})$ at controlled temperature (water bath at $90 \pm 50^{\circ} \mathrm{C}$ ) for one hour. The acids used are of the analytical type.

The solution obtained is consequently brought to $100 \mathrm{~mL}$ by way of demineralized water with a conductivity of less than $2 \mu \mathrm{S} / \mathrm{cm}$.

Elements of interest were analyzed by atomic absorption spectrophotometry. The modes used depend on the properties of the elements. So:

1) The flame mode was used for the analysis of chromium $(\mathrm{Cr})$, manganese $(\mathrm{Mn})$, iron $(\mathrm{Fe})$, nickel $(\mathrm{Ni})$, copper $(\mathrm{Cu})$ and zinc $(\mathrm{Zn})$;

2) The oven mode was used for the analysis of arsenic (As), cadmium $(\mathrm{Cd})$ and lead $(\mathrm{Pb})$;

3)Hydride generation (FIAS) or cold vapor was used for the analysis of mercury $(\mathrm{Hg})$.

The characteristics of the equipment used are:

1) Model AANALYST 200 from PERKIN ELMER for flame mode;
2) PERKIN ELMER PinnAcle900t model for oven mode and hydride generation.

The analysis results are valid on the basis of the performance of the analysis methods used (limit of detection and quantification, data of duplicates and reference materials inserted in the chemical preparation of the samples, selectivity of the method, the robustness of the method, data for control solutions, data for chemical blanks, etc.).

\subsection{Quantification of the Soil Pollution}

In this study, to quantify the degree of pollution in the refuse dump soils the geoaccumulation index, Igeo, was used $[3,4,10]$ :

$$
I_{g e o}=\ln \left(\frac{C_{n}}{1,5 B_{n}}\right)
$$

Where: $\mathrm{C}_{\mathrm{n}}$ : measured concentration of metal in the refuse dump soil $(\mu \mathrm{g} / \mathrm{g})$;

$B_{n}$ : background value of heavy metal $(\mu \mathrm{g} / \mathrm{g})$;

and 1.5: background matrix correction factor.

The degree of pollution of the refuse dumps by the metals was assessed (table 2) using the geoaccumulation index (igeo) classification (table 2) by Förstner et al. [10].

Table 2. Geoaccumulation index classification.

\begin{tabular}{lll}
\hline Geoaccumulation index, $\mathbf{I}_{\text {geo }}$ & $\mathbf{I}_{\text {geo }}$ class & Contamination intensity \\
\hline$>5$ & 6 & very strong \\
$>4-5$ & 5 & strong to very strong \\
$>3-4$ & 4 & strong \\
$>2-3$ & 3 & moderate to strong \\
$>1-2$ & 2 & moderate \\
$>0-1$ & 1 & uncontaminated to moderate \\
$<0$ & 0 & practically uncontaminated \\
\hline
\end{tabular}

\section{Results and Discussions}

\subsection{Concentration of Heavy Metals in the Soil of the Landfills Studied}

Table 3 presents the average concentrations of heavy metals at the different study sites and the average concentration of the geological background (which will be taken as a reference point).

Table 3. Average concentration (ppm) of heavy metals in some landfill soils.

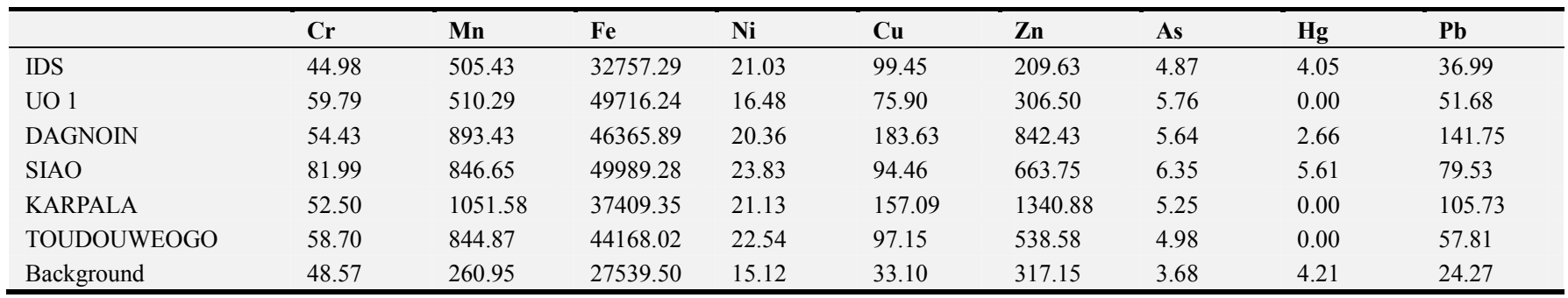

Chromium: the average concentration varies from 44.98 ppm to $81.99 \mathrm{ppm}$ depending on the landfills studied. The background concentration is $48.57 \mathrm{ppm}$. Only the soils of the Institute of Science landfill show an average chromium 
concentration lower than the background concentration. Landfills contribute to increased chromium concentration in the soil.

Manganese: the average manganese concentration was between $505.43 \mathrm{ppm}$ to $1051.58 \mathrm{ppm}$. The background concentration was $260.95 \mathrm{ppm}$ and very low than the manganese concentration; which reflects a strong contribution of landfills on the evolution of manganese concentration in soils.

Iron: The highest average iron concentration was $49,989.28$ ppm and observed in the soils of the SIAO landfill. The background iron concentration was 27,539.50 ppm, which was lower than the lowest concentration $(32,757.29$ $\mathrm{ppm})$, reflecting the impact of landfills on increasing iron concentration in soils.

Nickel: the lowest average concentration of nickel was $16.48 \mathrm{ppm}$ and measured in the soils of the University of Ouagadougou landfill (UO1). This concentration being higher than the background concentration, this explains the contribution of landfills on the nickel concentration in soils.

Copper: the average copper concentrations measured in landfill soils varied between $75.90 \mathrm{ppm}$ and $183.63 \mathrm{ppm}$ but the concentration obtained in the background was $33.10 \mathrm{ppm}$; which shows a strong contribution of landfills in the evolution of copper concentration in soils.

Zinc: The mean concentrations of zinc observed in the landfills of IDS (209.63 ppm) and UO1 (306.50 ppm) were lower than the background concentration which was set at $317.15 \mathrm{ppm}$. The landfills of IDS and UO1 do not contribute to changes of zinc concentration in soils.

Arsenic: the discharges studied all contribute to the evolution of the concentration of arsenic in the soils because the measurements obtained in this study was lower than that of the concentration background (3.68 ppm).

Mercury: the concentration of mercury in the background was $4.21 \mathrm{ppm}$. Only the soil from the SIAO landfill with a mercury concentration of $5.61 \mathrm{ppm}$ contributed to the change in the mercury concentration in the soil.

Lead: The smallest lead concentration obtained in this study was $36.99 \mathrm{ppm}$ on the IDS landfill. This concentration was higher than that of the background which is $24.27 \mathrm{ppm}$; which reflects the contribution of landfills in the evolution of mercury concentration in soils.

In conclusion, this study reveals that the studied landfills contribute to an increase in the concentration of heavy metals ( $\mathrm{Cr}, \mathrm{Mn}, \mathrm{Fe}, \mathrm{Ni}, \mathrm{Cu}, \mathrm{Zn}, \mathrm{As}, \mathrm{Hg}$ and $\mathrm{Pb}$ ) in soils.

\subsection{Physico-chemical Parameter of Landfill Soils}

Table 4 presents the $\mathrm{pH}-\mathrm{H}_{2} \mathrm{O}, \mathrm{pH}-\mathrm{KCl}$, the electrical conductivity, apparent density, the total organic matter, the carbon-nitrogen ratio and the assimilable phosphorus of the studied landfills soils. The $\mathrm{pH}-\mathrm{H}_{2} \mathrm{O}$ ranges from 5.84 to 7.32 and the $\mathrm{pH}-\mathrm{KCl}$ ranges from 5.14 to 6.62 .

Table 4. Physico-chemical parameter of landfill soils.

\begin{tabular}{llllllll}
\hline & $\mathbf{p H}-\mathbf{H}_{2} \mathbf{O}$ & $\mathbf{p H ~ K C l}$ & $\begin{array}{l}\text { Electrical } \\
\text { conductivity }\end{array}$ & Apparent density & $\begin{array}{l}\text { Total organic } \\
\text { matter \% }\end{array}$ & $\begin{array}{l}\text { Carbon } \\
\text { Nitrogen ratio }\end{array}$ & $\begin{array}{l}\text { Assimilable } \\
\text { phosphorus ppm }\end{array}$ \\
\hline IDS & 7.01 & 6.46 & 1.44 & 1.60 & 1.82 & 12.50 & 4.95 \\
UO 1 & 5.84 & 5.14 & 2.49 & 1.59 & 2.19 & 11.00 & 7.62 \\
DAGNOIN & 6.88 & 6.22 & 2.10 & 1.57 & 1.46 & 11.50 & 4.63 \\
SIAO & 7.32 & 6.46 & 0.89 & 1.60 & 1.46 & 12.00 & 13.46 \\
KARPALA & 6.92 & 5.88 & 0.69 & 1.56 & 0.73 & 12.00 & 7.46 \\
TOUDOUWEOGO & 7.16 & 6.62 & 0.39 & 1.56 & 2.19 & 13.00 & 3.73 \\
\hline
\end{tabular}

The $\mathrm{pH}-\mathrm{KCl}$ must be considered as the "pH" of the soil since it takes into account all the physicochemical characteristics [11]. So the soil $\mathrm{pH}$ of the studied landfills was less than 7 , which reflects the acidic nature of the studied landfill soils. The three parameters that influence the mobility of heavy metals are organic matter, soil texture and soil $\mathrm{pH}[11,12]$. The variation in $\mathrm{pH}$ easily modifies the behavior of metals in the soil. The complexation mechanism seems to promote landfills of IDS, DAGNOIN, SIAO and TOUDOUWEOGO on soils because the $\mathrm{pH}$ is greater than 6 .

Soil with an organic matter content of at least $5 \%$ and a pH greater than 5, promotes lead accumulation and allows better adsorption of zinc $[11,13,14]$. In this study, the organic matter varies between $0.73 \%$ to $2.19 \%$ on the soil of the studied landfills, therefore less than $5 \%$, moreover the $\mathrm{pH}$ is higher than 5 . These results of $\mathrm{pH}$ and organic matter could favor the accumulation of lead and allow better adsorption of zinc on soils.

When the $\mathrm{pH}$ is high, copper is fixed to the oxides of iron, of manganese, argil and organic matter.

In soils, the main form of chromium is chromium III and a small proportion of chromium VI. Under anaerobic conditions and low $\mathrm{pH}(\mathrm{pH}<5)$, chromium III in soils and in sediments results from the transformation of chromium VI. In addition in the soil, chromium III is absorbed more easily than chromium VI. In the soils of the studied landfills, the predominant form of chromium would be chromium VI, which is more bioavailable and potentially toxic $[11,15]$. This could justify the mobility of chromium in the soils of the landfills. Iron occurs regularly in reduced form $\left(\mathrm{Fe}^{2+}\right)$ and is quite mobile in acidic soils [11]. In this study, the $\mathrm{pH}$ were acidic, this will cause iron mobility in the soil of the studied landfills. 


\subsection{Quantification of Soil Pollution by Heavy Metal}

Table 5. Index of geo-accumulation (Igeo) of heavy metal in every site and classification.

\begin{tabular}{llllllllll}
\hline Ig & $\mathbf{C r}$ & $\mathbf{M n}$ & $\mathbf{F e}$ & $\mathbf{N i}$ & $\mathbf{C u}$ & $\mathbf{Z n}$ & $\mathbf{A s}$ & $\mathbf{H g}$ & $\mathbf{P b}$ \\
\hline IDS & -0.482 & 0.256 & -0.232 & -0.076 & 0.695 & -0.820 & -0.126 & -0.445 & 0.016 \\
UO 1 & -0.198 & 0.265 & 0.185 & -0.319 & 0.424 & -0.440 & 0.043 & - & 0.350 \\
DAGNOIN & -0.292 & 0.825 & 0.115 & -0.108 & 1.308 & 0.571 & 0.022 & -0.866 & 1.359 \\
SIAO & 0.118 & 0.771 & 0.191 & 0.049 & 0.643 & 0.333 & 0.140 & -0.118 & 0.781 \\
KARPALA & -0.328 & 0.988 & -0.099 & -0.071 & 1.152 & 1.036 & -0.050 & - & 1.066 \\
TOUDOUWEOGO & -0.216 & 0.769 & 0.067 & -0.006 & 0.671 & 0.124 & -0.103 & - & 0.462 \\
\hline
\end{tabular}

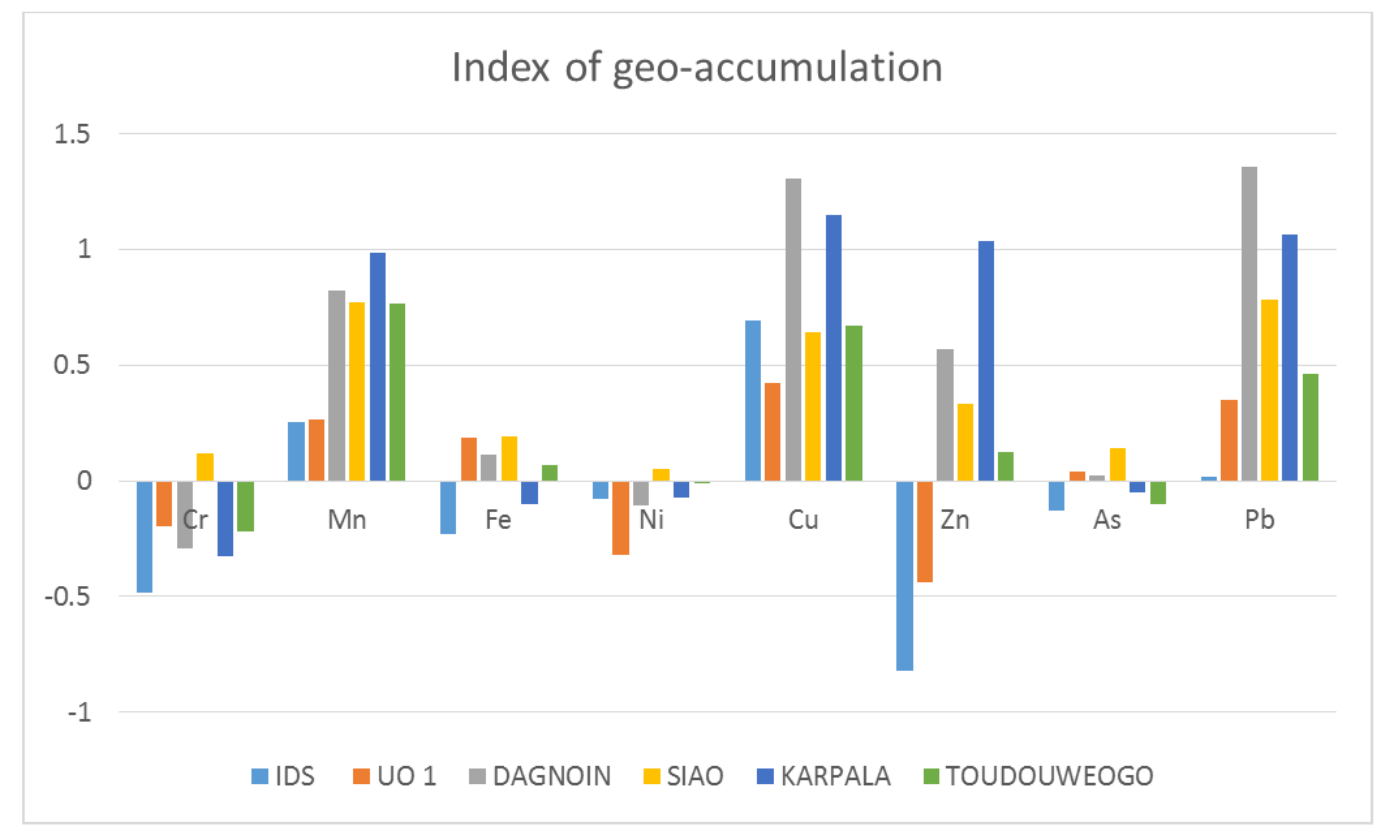

Figure 1. Geo-accummulation indices (Igeo) of heavy metal in every site.

The table 5 and figure 1 shown the variation and the value of geo-accumulation indices for each heavy metal.

The geo-accumulation indices various between $-0,820$ to 0,695 in landfill soil from Institute of sciences (IDS). The pollution levels in landfill soil from Institute of IDS for $\mathrm{Cr}$, $\mathrm{Fe}, \mathrm{Ni}, \mathrm{Zn}$ and As were practically uncontaminated but uncontaminated to moderate for $\mathrm{Mn}, \mathrm{Cu}$ and $\mathrm{Pb}$.

The maximal value of geo-accumulation indices was 0,424 in the landfill soil from University of Ouagadougou (UO1). The metal who contribute more to the soil pollution at University of Ouagadougou ( $\mathrm{UO} 1$ ) was $\mathrm{Cu}$, with a level of uncontaminated to moderate.

The pollution levels in soil from DAGNOIN landfill were uncontaminated except for $\mathrm{Cu}$ and $\mathrm{Pb}$ with the geoaccumulation indices values of 1,308 and 1,359 respectively.

The pollution levels in landfill soil from SIAO and TOUDOUWEOGO were uncontaminated for all metal. In KARPALA landfill soil, the pollution levels for $\mathrm{Cu}, \mathrm{Zn}$ and $\mathrm{Pb}$ were moderate.

In conclusion, the classifications show that the landfill soil from KARPALA and DAGNOIN were the moderate polluted with $\mathrm{Cu}, \mathrm{Zn}$ and $\mathrm{Pb}$. And the landfill soil from Institute of Sciences (IDS) was the least polluted with the metals. The $\mathrm{Cu}, \mathrm{Zn}$ and $\mathrm{Pb}$ were metal that contribute more in the pollution in the landfill soil at Ouagadougou.

\subsection{Statistical Analysis}

The normalized principal component analysis (NPCA) applied to soil samples was performed with R software.

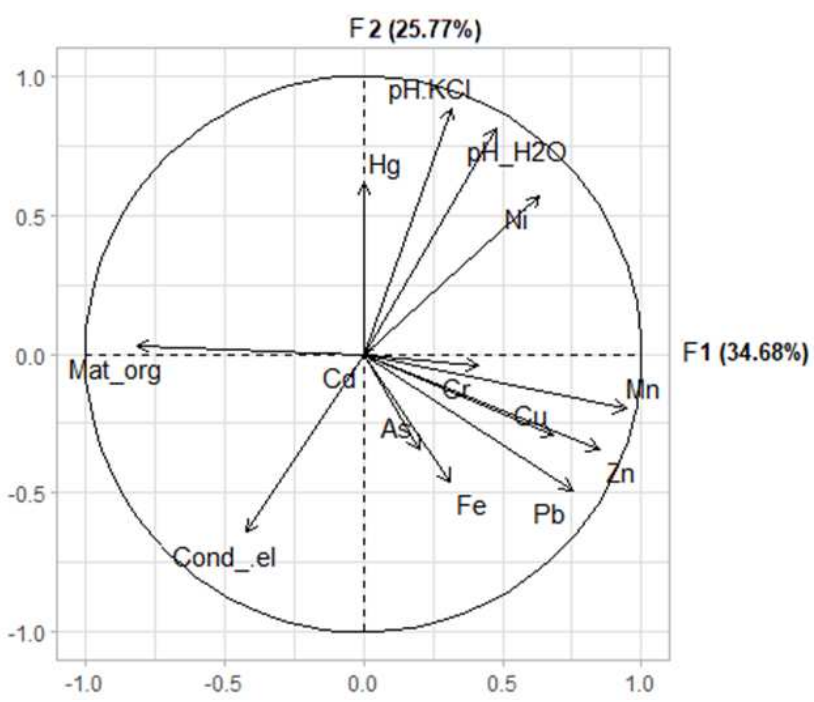

Figure 2. Community circle of the factorial plane F1 - F2.

The analysis of the community circle (Figure 2) allows to 
identify two main groups of parameters. The first group $\left(\mathrm{G}_{1}\right)$ consists of $\mathrm{Hg}, \mathrm{Ni}$, $\mathrm{pH}-\mathrm{H}_{2} \mathrm{O}$ and $\mathrm{pH}-\mathrm{KCl}$. The second group $\left(\mathrm{G}_{2}\right)$ is formed by the parameters $\mathrm{Cu}, \mathrm{Pb}, \mathrm{Mn}$ and $\mathrm{Zn}$. The grouping of the two communities of parameters is done in the positive part of the factor F1 axis.

Table 6. ACPN correlation matrix.

\begin{tabular}{|c|c|c|c|c|c|c|c|c|c|c|c|c|c|}
\hline variables & $\mathrm{Cr}$ & Mn & $\mathrm{Fe}$ & $\mathrm{Ni}$ & $\mathbf{C u}$ & Zn & As & $\mathrm{Hg}$ & $\mathbf{P b}$ & pH_H ${ }_{2} \mathrm{O}$ & pH.KCl & Cond_el & Mat_org \\
\hline $\mathrm{Cr}$ & 1.00 & & & & & & & & & & & & \\
\hline $\mathrm{Mn}$ & 0.34 & 1.00 & & & & & & & & & & & \\
\hline $\mathrm{Fe}$ & 0.78 & 0.33 & 1.00 & & & & & & & & & & \\
\hline $\mathrm{Ni}$ & 0.37 & 0.50 & -0.04 & 1.00 & & & & & & & & & \\
\hline $\mathrm{Cu}$ & -0.08 & 0.68 & 0.10 & 0.41 & 1.00 & & & & & & & & \\
\hline $\mathrm{Zn}$ & 0.18 & 0.92 & 0.21 & 0.23 & 0.59 & 1.00 & & & & & & & \\
\hline As & 0.72 & 0.15 & 0.72 & -0.22 & -0.22 & 0.21 & 1.00 & & & & & & \\
\hline $\mathrm{Hg}$ & 0.21 & -0.29 & -0.04 & 0.16 & -0.32 & -0.30 & 0.36 & 1.00 & & & & & \\
\hline $\mathrm{Pb}$ & 0.14 & 0.78 & 0.41 & 0.12 & 0.78 & 0.77 & 0.32 & -0.16 & 1.00 & & & & \\
\hline pH_H2O & 0.16 & 0.31 & -0.22 & 0.67 & -0.02 & 0.17 & -0.03 & 0.59 & 0.04 & 1.00 & & & \\
\hline pH.KCl & 0.04 & 0.13 & -0.24 & 0.69 & 0.03 & -0.09 & -0.24 & 0.56 & -0.07 & 0.92 & 1.00 & & \\
\hline Cond_.el & -0.28 & -0.30 & -0.01 & -0.56 & 0.06 & -0.19 & 0.16 & -0.24 & 0.19 & -0.62 & -0.59 & 1.00 & \\
\hline Mat_org & -0.11 & -0.71 & 0.03 & -0.39 & -0.61 & -0.82 & -0.08 & -0.07 & -0.59 & -0.31 & -0.09 & 0.36 & 1.00 \\
\hline
\end{tabular}

The analysis of the correlation matrix (Table 6), allows to note strong correlations between the parameters As and $\mathrm{Cr}$ (0.72), As and $\mathrm{Fe}(0.72), \mathrm{Cr}$ and $\mathrm{Fe}(0.78), \mathrm{Mn}$ and $\mathrm{Zn}(0.92)$, $\mathrm{Mn}$ and $\mathrm{Cu}$ (0.68), $\mathrm{Mn}$ and $\mathrm{Pb}(0.78), \mathrm{Zn}$ and $\mathrm{Pb}(0.77)$, and $\mathrm{Cu}$ and $\mathrm{Pb}(0.78)$. These strong correlations allows to say that these parameters are governed by the same mechanism.

On the other hand, the positive and significant correlations between $\mathrm{pH}-\mathrm{KCl}$ and $\mathrm{Ni}(0.69)$, and between $\mathrm{pH}$ and $\mathrm{Ni}$ (0.67) reflect the influence of $\mathrm{pH}$ in the adsorption of nickel. The negative and significant correlations between Mat_org and $\mathrm{Mn}$ (-0.71), $\mathrm{Zn}(-0.82), \mathrm{Cu}(-0.61)$ and $\mathrm{Pb}(-0.59)$ indicate that the value of total organic matter tends to increase when the concentrations of manganese, zinc, copper and lead decrease.

\section{Conclusion}

This study showed that the studied landfills contribute to increase the concentration of heavy metals $(\mathrm{Cr}, \mathrm{Mn}, \mathrm{Fe}, \mathrm{Ni}$, $\mathrm{Cu}, \mathrm{Zn}, \mathrm{As}, \mathrm{Hg}$ and $\mathrm{Pb}$ ) in soils. The $\mathrm{pH}-\mathrm{KCl}$ of the landfills studied were less than 7. The complexation mechanism is favored on the landfills soils of IDS, DAGNOIN, SIAO and TOUDOUWEOGO. The values of $\mathrm{pH}$ and organic matter promote the accumulation of lead, allow better adsorption of zinc on the soils and mobility of chromium and iron in the soils of the studied landfills. The landfill soil from KARPALA and DAGNOIN were the moderate polluted with $\mathrm{Cu}, \mathrm{Zn}$ and $\mathrm{Pb}$. The landfill soil from Institute of Sciences (IDS) was the least polluted with the heavy metals. The $\mathrm{Cu}$, $\mathrm{Zn}$ and $\mathrm{Pb}$ were metal that contribute more in the pollution in the landfill soil at Ouagadougou. An increase of the total organic material causes a reduction of the concentrations of manganese, zinc, copper and lead.

\section{Acknowledgements}

The Institute of Sciences is appreciated for providing the financial resources to conduct this study.

\section{References}

[1] Institut National de la Statistique et de la Démographie (INSD), BURKINA FASO, projection 2020. https://www.insd.bf/index.php/publications?id=36

[2] Peace Makuleke and Veronica M. Ngole-Jeme (2020). Soil Heavy Metal Distribution with Depth around a Closed Landfill and Their Uptake by Datura stramonium. Hindawi, Applied and Environmental Soil Science, Volume 2020, $\begin{array}{llll}\text { Article ID } & 8872475, & 14 & \text { pages. }\end{array}$ https://doi.org/10.1155/2020/8872475

[3] Agyarko K., Darteh E., Berlinger B. (2010). Metal levels in some refuse dump soils and plants in Ghana. Plant Soil Environ., 56, 2010 (5): 244-251

[4] Hashim M. Jafaru, G. N. N. Dowuona, Thomas A. Adjadeh, Eric K. Nartey, P. M. Nude and Dora Neina (2015). Geochemical Assessment of Heavy Metal Pollution as Impacted by Municipal Solid Waste at Abloradjei Waste Dump Site, Accra-Ghana. Research Journal of Environmental and Earth Sciences 7(3): 50-59, 2015, ISSN: 2041-0484; e-ISSN: 20410492, (C) 2015 Maxwell Scientific Publication Corp.

[5] Nhari F., M. Sbaa, J. L. Vasel, M. Fekhaoui, M. El Morhit, (2014). Contamination des sols d'une décharge non contrôlée par les métaux lourds: cas de la décharge Ahfir- Saidia (Maroc oriental) [Soil contamination of the landfill uncontrolled by heavy metals: case of the landfill of Ahfir-Saidia (Eastern Morocco)]; J. Mater. Environ. Sci. 5 (5) (2014) 1477-1484, ISSN: 2028-2508 CODEN: JMESCN.

[6] Biaou Chérifatou Iyabo, Sidonie Clarisse Hedible, Rodrigue Codjo Landeou, Pierre PAGNEY (2019). Impact des Décharges Sauvages des Déchets Solides sur les Sols à Cotonou European Scientific Journal October 2019 edition Vol.15, No.30 ISSN: 1857 - 7881 (Print) e - ISSN 1857- 7431

[7] ADJIRI Oi Adjiri, Droh Lanciné GONE, Innocent K. KOUAME, Bamory KAMAGATE et Jean BIEMI (2008). Caractérisation de la pollution chimique et microbiologique de l'environnement de la décharge d'Akouédo, Abidjan-Côte d'Ivoire; Int. J. Biol. Chem. Sci. 2(4): 401-410, 2008; ISSN 1991-8631. 
[8] BODJONA Magnoudéwa B., Koffi A. KILI, Sanonka TCHEGUENI 1, Bouchra KENNOU, Gado TCHANGBEDJI et Mohamed El MERAY (2012). Evaluation de la quantité des métaux lourds dans la décharge d'Agoè (LoméTogo): cas du plomb, cadmium, cuivre, nickel et zinc; Int. J. Biol. Chem. Sci. 6(3): 1368-1380, June 2012, ISSN 1991-8631.

[9] Joshua N. Edokpayi, Olatunde S. Durowoju and John O. Odiyo (2018). Assessment of Heavy Metals in Landfill Leachate: A Case Study of Thohoyandou Landfill, Limpopo Province, South Africa. IntechOpen, http://dx.doi.org/10.5772/intechopen.74009

[10] Förstner U., ahlf W., Calmano W. (1993): Sediment quality objectives and criteria development in Germany. Water Science and technology, 28: 307.

[11] KOUAME I. K., GONE D. L., SAVANE I., KOUASSI E. A., KOFFI K., GOULA B. T. A. et DIALLO M., (2006) «Mobilité relative des métaux lourds issus de la décharge d'Akouédo et risque de contamination de la nappe du Continental Terminal (Abidjan - Côte d'Ivoire)». Afrique SCIENCE 02(1) (2006) 39 - 56 ISSN 1813-548X.

[12] MARTINELLI I., (1999) «Infiltration des eaux de ruissellement pluvial et transfert de polluants associés dans le sol urbain -Vers une approche globale et pluridisciplinaire». Thèse de Doctorat, spécialité Conception en bâtiment et techniques urbaines, Institut National des Sciences Appliquées de Lyon, (1999) 207 p.

[13] PICHARD A., BISSON M., HULOT C., LEFEVRE J. P., MAGAUD H., OBERSON G., MORIN A. D., PEPIN G., (2002) «Fiche de données toxicologiques et environnementales des substances chimiques: Plomb et ses dérivés». INERIS-DRC-01-25590 - ETSC - APi/SD, $\mathrm{N}^{\circ} 00 \mathrm{df257}$ _version2.doc, (2002) 83p.

[14] PICHARD A., BISSON M., DIDERICH R., HOUEIX N., HULOT C., LACROIX G., LEFEVRE J. P., LEVEQUE S., MAGAUD H., MORIN A., PEPIN G., (2003) «Fiche de données toxicologiques et environnementales des substances chimiques: Zinc et ses dérivés». INERIS-DRC-01-25590ETSC - APi/SD, Nº0df259, (2003) 63p.

[15] PICHARD A., BISSON M., DIDERICH R., HOUEIX N., HULOT C., LACROIX G., LEFEVRE J. P., LEVEQUE S., MAGAUD H., MORIN A., ROSE M., PEPIN G., (2004) «Fiche de données toxicologiques et environnementales des substances chimiques: Chrome et ses dérivés inorganiques». INERIS-DRC-01-25590 - ETSC - APi/SD, Nº0df253, (2004) 68p. 